

ARASTIRMA MAKALESI

\title{
Termal Turizm Konulu Lisansüstü Tezlerin Bibliyometrik Analizi
}

Dr. Öğr. Üyesi Gözde OĞUZBALABAN, Zonguldak Bülent Ecevit Üniversitesi, Turizm Fakültesi, Zonguldak, e-posta: oguzbalaban@beun.edu.tr

ORCID: https://orcid.org/0000-0002-0582-379X

Öz

Bu çalışmada, Yükseköğretim Kurumu Ulusal Tez Merkezi (YÖKTEZ) veri tabanında "termal turizm" alanında yayımlanan lisansüstü tezlerin bibliyometrik analizi gerçekleştirilmiş̧ir. Bu amaçla, çalışmada 1988-2018 yılları arasında termal turizm ile ilgili yayımlanan 65'i yüksek lisans tezi ve 11'i doktora tezi olmak üzere toplam 76 lisansüstü tezi araştırma kapsamına dahil edilmiştir. Bu tezler, "tamamlandığı yıl", "üniversitesi", "enstitüsü", "anabilim dalları", "kullanılan anahtar kelimeler", "araştırma yöntemleri", "veri toplama teknikleri", "örneklem grubu" ve "araştırma konuları" kriterlerine göre incelenmiştir. Lisansüstü tezlerle ilgili bu bilgiler SPSS programına yüklenerek, verilerin sıklık ve yüzde analizleri yapılmıştır. Araştırma bulgularına göre, yüksek lisans düzeyindeki araştırmaların doktora düzeyindeki araştırmalara kıyasla ağırlıkta olduğu; termal turizm ile ilgili en fazla tezin Afyon Kocatepe Üniversitesi bünyesinde hazırlandığı belirlenmiştir. Tezlerin çoğunluğunun özellikle İşletme Anabilim Dalı altında gerçekleştirildiği; yönetim ve organizasyon disiplinine yönelik konuların da ilk sırada yer aldığı tespit edilmiştir. Tezlerin araştırma yöntemleri incelendiğinde en çok nicel yöntemin ve anket tekniğinin tercih edildiği; örneklem gruplarında ise en fazla yerli turistlerin yer aldığ görülmüştür.

Anahtar Kelimeler: Turizm, Termal Turizm, Bibliyometrik Analiz, Lisansüstü Tezler.

Makale Gönderme Tarihi: 05.06.2019

Makale Kabul Tarihi: 04.10.2019

\section{Önerilen Atıf:}

Oğuzbalaban, G. (2019). Termal Turizm Konulu Lisansüstü Tezlerin Bibliyometrik Analizi, Türk Turizm Araştırmaları Dergisi, 3(4): 1012-1027.

(c) 2019 Türk Turizm Araştırmaları Dergisi. 


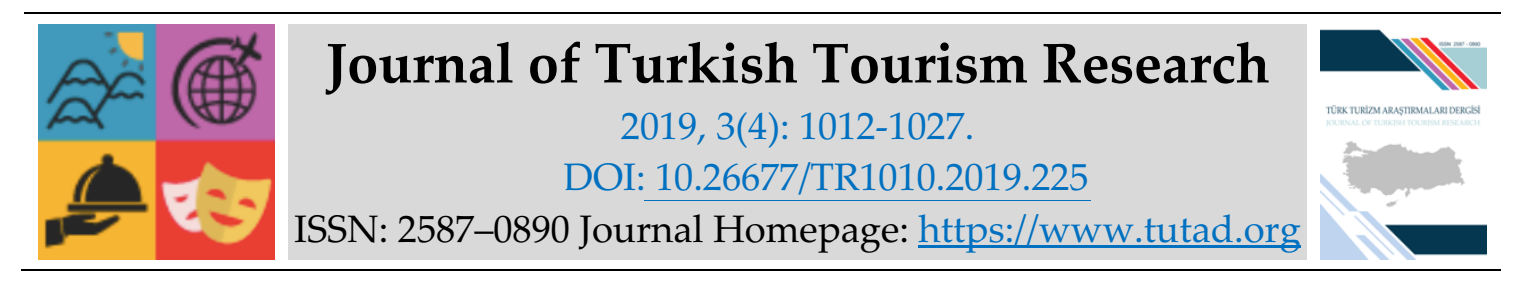

\title{
$\underline{\text { RESEARCH PAPER }}$
}

\section{Bibliometric Profile of Postgraduate Theses in Tourism Literature Related with Thermal Tourism}

Assistant Prof. Dr. Gözde OĞUZBALABAN, Zonguldak Bülent Ecevit University, Faculty of Tourism, Zonguldak, e-mail: oguzbalaban@beun.edu.tr ORCID: https://orcid.org/0000-0002-0582-379X

\begin{abstract}
In this study, bibliometric analysis of postgraduate theses which are published in the field of "thermal tourism" in database of Higher Education Institution National Thesis Center (YÖKTEZ) was performed. For this purpose, a total of 76 postgraduate theses, 65 master theses and 11 doctoral dissertation which were published related to thermal tourism between 1988-2018, were included in the scope of the study. These theses were reviewed according to "the year completion", "university", "institute", "departments", "used keywords", "research methods", "data collection techniques", "sample group" and "research subjects" criteria. This information related to postgraduate theses were loaded to SPSS program to make frequency and percentage analyses of the data. According to research findings, it was determined that the number of master studies were more than the studies at doctorate level; and that the theses related to thermal tourism were most prepared within Afyon Kocatepe University. It was identified that most of the theses were particularly made under Business Management department; and that the topics towards management and organization discipline ranked first. When research methods of the theses are reviewed, it is observed that quantitative method and questionnaire technique were preferred the most; and that local tourists were the most included ones in sample groups.
\end{abstract}

Keywords: Tourism, Thermal Tourism, Bibliometric Analysis, Postgraduate Theses.

Received: 05.06.2019

Accepted: 04.10.2019

\section{Suggested Citation:}

Oğuzbalaban, G. (2019). Bibliometric Profile of Postgraduate Theses in Tourism Literature Related with Thermal Tourism, Journal of Turkish Tourism Research, 3(4): 1012-1027.

(C) 2019 Türk Turizm Araştırmaları Dergisi. 


\section{Gíriş}

Geçmişten beri insanların sağlık amaçlı olarak seyahat ettikleri ve gittikleri yerlerde rahatsızlıklarına çare aradıkları bilinmektedir. Günümüzde ise kent yaşamının ve sanayileşmenin ortaya çıkardığı çevre sorunları hem gelişmiş hem de gelişmekte olan ülkelerde yaşayan insanların mineralli termal suların olduğu yerleri tercih etmelerine neden olmaktadır (Zengin ve Eker, 2016: 166). Bu durum termal turizmin ortaya çıkmasında rol oynamıştır. Özellikle son on yılda gelişen termal turizm; belirli sıcaklığa sahip olarak doğal şekilde yer üstüne çıkan ve faydalı mineralleri içeren şifalı suların yanında şifalı çamurların ve buharlarında bulunduğu yörelerde, kendine özgü iklim şartlarında gerçekleşen turizm türüdür (Tutar, 1991).

Turizm türlerinden biri olan termal turizm ile ilgili çalışmaların nicelik ve nitelik olarak incelenmesi, bu alanda araştırma yapmak isteyenlere yol gösterici olacağı düşünülmektedir. Literatür taraması yapıldığında turizm alanı ile ilgili makale, bildiri ve tezlerle ilgili olmak üzere birçok bibliyometrik analiz çalışması yapıldığı görülmektedir. Bibliyometrik analiz çalışmaları, çalışmaların süreç içerisindeki tarihsel gelişimini, çalışma alanının yöneldiği seyri de göz önüne sermeye yarayan bir yöntem olarak da bilinmektedir (Barrios vd., 2008). Daha ayrıntılı ele alındığında, bibliyometrik araştırmalar; ilgili bilim dalının göstermiş olduğu gelişimin görülmesine, bu alandaki eksikliklerin ve sorunların ortaya çıarılmasına ve bu bağlamda yapılacak düzeltmeler ve getirilecek öneriler ile bilim dalının geliştirilmesine ve tartışılmasına olanak sağlamaktadır (Yılmaz, 2017). Bibliyometrik araştırmalarda belgelerin ya da yayınların belirli özellikleri çözümlenerek çeşitli bulgular elde edilmektedir. Bu özellikler arasında; yayın türü (tez, bildiri, makale, kitap vb.), yayın yeri (üniversite, kongre, dergi, kurum vb.), yazar (kurum, unvan, bölüm vb.), yayın dili, araştırma alanı/konusu, atıf, atıf yapılan dergi/yazar, referans kaynak (türü, yaşı, dili, vb.), sayfa sayısı ve anahtar kelime gibi birçok gösterge bulunmaktadır. Bibliyometrik çalışmalardan ortaya çıkan sonuçlar ile ülkelerin veya kurumların bilimsel gelişmişliği ortaya konulmaktadır. Bu doğrultuda bibliyometrik analiz çalışmaları zaman içerisinde artış göstererek, son yıllarda ilgi odağı haline geldiği görülmüştür (Baytok, vd.,2019:289).

Literatür taraması sonucunda, termal turizm ile ilgili herhangi bir bibliyometrik analiz çalışmaya rastlanmamıştır. Bu husustaki boşluğu doldurabilmek adına, bu çalışmada; 1988-2019 yılları arasında Yükseköğretim Kurumu Ulusal Tez Merkezi (YÖKTEZ) veri tabanında yer alan termal turizm konusunda hazırlanan yüksek lisans ve doktora tezleri incelenmiştir. Özel ve Kozak'ın (2012) da ifade ettiği üzere; turizmin farklı alt konu başlıklarında yapılacak bibliyometrik çalışmalar, çalışılan alanlara ilişkin kapsamlı bir bakış açısı sağlamaktadır. Bu çalışmanın genel amacı, termal turizm alanında hazırlanan yüksek lisans ve doktora tezlerinin zaman içerisinde gösterdiği gelişmeye işık tutmaktır. Dolayısıyla bu çalışmadan elde edilecek bulgular, termal turizm konusunda yayımlanan yüksek lisans ve doktora tezleri ile ilgili sayısal verilerle birlikte bir bakış açısı ortaya koyması ve bu alandaki eksikliği doldurması açısından önemli görülmektedir.

\section{LİTERATÜR İNCELEMESİ}

Uluslararası literatürde turizmle ilgili tezlerin incelenmesine yönelik bibliyometrik çalışmalar (Meyer-Arendt, 2000; Bao, 2002; Meyer-Arendt ve Justice, 2002; Afifi, 2009; Weiler vd., 2018) olduğu gibi, Ulusal literatürde de turizmle ilgili tezlerin incelenmesine yönelik bibliyometrik çalışmaların (Güçlü Nergiz, 2014; Tayfun vd., 2016; Tekin, 2016; Civelek Oruç ve Türkay, 2017; Kılıç vd., 2017; Güdü Demirbulat ve Tetik Dinç, 2017; Sünnetçioğlu vd., 2017; İnce vd., 2017; Altaş ve Acar, 2018; Şahin vd., 2018; Ayaz ve Türkmen, 2018; Tayfun vd., 2018; Kervankıran ve Şardağ, 2019; Baytok vd.,2019) olduğu belirlenmiştir. Konu ile ilgili literatürde yer alan bazı çalışmalar hakkında aşağıda kısaca bilgi verilmektedir. 
Afifi (2009) çalışmasında, 1975-2008 yılları arasında Mısır'da yer alan Helwan Üniversitesi, Alexandria Üniversitesi ve EI-Fayoum Üniversitesi bünyesinde hazırlanan, turizm alanı ile ilgili doktora düzeyindeki tezleri incelemiştir. Araştırmacı, toplam 61 teze ulaşmış olup, tezlerden 6 tanesi tamamlanmadığından dolayı 55 tezi araştırma kapsamına dahil etmiştir. Doktora tezlerinin çoğunluğunun \%78,2'si Helwan Üniversitesi bünyesinde tamamlandığı belirlenmiştir. Çalışma konuları incelendiğinde, "turizm pazarlaması" ve "turizm planlaması ve gelişimi", konuları birlikte araştırılan konuların \%38,2'sini temsil ederken, "turizm ekonomisi", "turizm yönetimi" ve "uluslararası politika", konuları araştııılan sorunların \%29,1'ini oluşturduğu tespit edilmiştir. Çalışmada tespit edilen önemli bulgulardan biri de doktorasını bitiren kişilerin \%70,9'nun akademik personel olduğu görülmüsstür.

Güçlü Nergiz (2014) çalışmasında, Türkiye'de 1990-2013 yılları arasında turizm alanında hazırlanan lisansüstü tezlerinin genel bir değerlendirmesini yapmıştır. 2.348 tez araştırma kapsamına dahil edilmiştir. Çalışmada tezleri "yıl", "dil", "tür", "üniversite", "anabilim dalı" "enstitü" ve "konu" gibi başlıklar açısından incelemiştir. Araştırma sonucunda, en fazla yüksek lisans tezinin Gazi Üniversitesi'nde, en fazla doktora tezinin ise Dokuz Eylül Üniversitesi'nde hazırlandığı belirlenmiştir.

Tayfun vd., (2016) çalışmalarında, 1985-2016 yılları arasında Gazi Üniversitesi bünyesinde hazırlanan turizm konulu 367 tezi incelemişlerdir. İncelenen tezlerde sınıflandırılma yapılırken "özet kurgusu", "lisansüstü düzeyi", "yararlanılan disiplin", "enstitü türü", "araştırma yılı" ve "danışman unvanı" esas almışlardır. Araştırma sonuçlarına göre; lisansüstü tezlerin özet kısmında, çoğunlukla amaç, yöntem ve sonuçtan bahsedilirken tartışma ve önerilere büyük oranda tezlerde yer verilmediği belirlenmiştir. Turizm içerikli tezlerin en çok eğitim bilimleri enstitüsü altında ve en fazla tezin 2012 senesinde tamamlandığı görülmüş̧tür.

Tekin (2016) çalışmasında, 1984- 2015 yılları arasında turizm ile ilgili anabilim dallarında hazırlanmış 1.370 lisansüstü tezini incelemiştir. Çalışmada, yıllar bazında hazırlanan tez sayıları, tez konuları, tez yazarları ve danışmanları, tezlerin hazırlandıkları anabilim dallarına ilişkin çeşitli veriler yer almıştır. Araştırma sonuçlarına göre, tezlerde odaklanılan konuların özellikle işletme disiplini ile ilgili olduğu, en fazla tezin Gazi Üniversitesi bünyesinde hazırlandığ belirlenmiştir.

Civelek Oruç ve Türkay (2017) çalışmalarında, 2013-2017 yılları arasında tamamlanan turizmle ilgili lisansüstü tezleri incelemişlerdir. Erişimine olanak tanınan 284 tez incelendiğinde, turizmle ilgili en fazla lisansüstü tezin Gazi Üniversitesi bünyesinde hazırlandığı, tezlerde en sık kullanılan yöntemin nicel yöntem olduğu belirlenmiştir.

Kılıç vd., (2017) çalışmalarında, 2007-2017 yılları arasında Yükseköğretim Kurumu Ulusal Tez Merkezi veri tabanında yer alan girişimcilik konulu 44 doktora ve 143 yüksek lisans tezi olmak üzere toplam 187 lisansüstü tezini incelemişlerdir. Araştırma sonucunda, girişimcilik alanında yazılan tezlerin çoğunlukla yüksek lisans düzeyinde olduğu, nicel araştırma yönteminin en sık kullanıldığı ve en fazla lisansüstü tezin Gazi Üniversitesi bünyesinde hazırlandığı belirlenmiştir.

Güdü Demirbulat ve Tetik Dinç (2017) çalışmalarında, sürdürülebilir turizm ile ilgili 1987-2015 yılları arasında hazırlanan 21 doktora ve 41 yüksek lisans tezini "yayınlandığı yıl", "yayınlandığ üniversite", "tez türü", "yayınlandığı enstitü", "yayınlandığı anabilim dalı" ve "tezin çalışma konusu" gibi başlıklarda incelenmişlerdir. Analiz sonucunda, sürdürülebilir turizm alanı ile ilgili en fazla tezin İstanbul Üniversitesi bünyesinde hazırlandığı görülmüştür.

Sünnetçioğlu vd., (2017) çalışmalarında, gastronomi alanı ile ilgili tezleri incelemişlerdir. Çalışmada, 33 adet lisansüstü teze ulaşılmıştır. Ulaşılan tezler de; "yayınlandığı yıl", "yayınlandığ1 üniversite", "tez türü", "sayfa sayısı", "kullanılan anahtar kelimeler", "tez 
konusu", danışman akademik unvanı, "araştırma yaklaşımı", "örnekleme grubu", "örnekleme tekniği" ve "veri toplama aracı" gibi başlıklar incelenmiştir. Yapılan bu çalışmada anahtar kelime olarak sadece "gastronomi" kelimesinin kullanılması çalışmanın bir sınırlılığıdır. Çalışma sonuçlarına göre, gastronomi alanı ile ilgili tezlerin çoğunlukla yüksek lisans tezi olduğu ve genellikle pazarlama içerikli hazırlandığı belirlenmiştir. Örneklem grubu olarak yabancı turistlerin daha sık tercih edildiği ve ulaşılan örneklem grubundan veri elde etmede en çok kullanılan veri toplama tekniğinin ise anket olduğu tespit edilmiştir.

İnce vd., (2017) çalışmalarında, 1990-2016 yılları arasında turizm pazarlaması konusunda yazılmış 177 lisansüstü tezi analiz etmişlerdir. Araştırma sonuçlarına göre, turizm pazarlaması konusunda en çok tez 2015 yılında tamamlanmıştır. Tezlerin büyük çoğunluğu yüksek lisans tezidir. Turizm pazarlaması konusunda en çok tez Gazi Üniversitesi ve Balıkesir Üniversitesi bünyesinde hazırlanmıştır. Tezlerde veriler en çok anket tekniği ile toplanmıştır.

Weiler vd., (2018) çalışmalarında, 1974- 2013 yılları arasında Amerika Birleşik Devletleri, Kanada, Avustralya ve Yeni Zelanda üniversitelerinde tamamlanan turizm psikolojisi ile ilgili doktora tezlerini incelenmişlerdir. 359 doktora tezini analiz etmişlerdir. Araştırmanın sonuçlarına göre, tezlerde kullanılan en yaygın kavramsal temalar; motivasyon, destinasyon seçimi, turist davranışları-deneyimleri ve tutumları-memnuniyetleri olduğu tespit edilmiştir. En çok sorgulanan teori ise beklenti ve değer teorisidir. Süreç içerisinde de karma ve nitel çalışmaların artış gösterdiği belirlenmiştir.

Altaş ve Acar (2018) çalışmalarında, 1987-2018 yılları arasında yapılan gastronomi alanı ile ilgili lisansüstü tezleri değerlendirmişlerdir. Bu amaçla Yükseköğretim Kurulu tez veri tabanında yayınlanan 42 yüksek lisans tezi ve 9 doktora tezini, "tez türü", "yayın yılı", "yayımlanmış üniversite", "yayımlanmış enstitü", "yayımlanmış bölüm", "sayfa sayısı", "tez çalışma alanı" başlıklarda bibliometrik özelliklerini incelemişlerdir. Araştırmanın sonucuna göre, üniversiteler arasında gastronomi alanı ile ilgili en fazla lisansüstü tezin Gazi Üniversitesi bünyesinde hazırlandığı ve gastronomi alanında en çok tezin 2016 yılında (15 adet) hazırlandığ1 tespit edilmiştir.

Şahin vd., (2018) çalışmalarında, Gastronomi ve Mutfak Sanatları Anabilim Dallarında yayımlanmış 23 lisansüstü tezi "yıllara göre dağılımı", "yayınlandığı üniversite", "yayınlandığ1 enstitü", "tezin temel çalışma alanı", "ilgili anabilim dalı", "danışman unvanı", "tezin sayfa sayısı", "tezin uygulama bölgesi", "örnekleme yöntemi", "örneklem grubu", "veri toplama yöntemi" ve "anahtar kelimeler" kriterlerine göre incelemişlerdir. Araştırmanın bulgularına göre, bu alanla ilgili hazırlanan tezlerin sayısının her geçen yıl hızla arttı̆̆ı, çalışma konularının ağırlıklı olarak "turizm" ve "beslenme" ile ilişkilendirildiği ve veri toplama aracı olarak ise en çok anket tekniğinden yararlanıldığı belirlenmiştir.

Ayaz ve Türkmen (2018) çalışmalarında, 1999-2017 yılları arasında yöresel yiyecekler ile ilgili Ulusal Tez Merkezi internet sitesinde yayımlanan lisansüstü tez çalışmalarını sınıflandırılarak analiz etmişlerdir. Araştırma kapsamında 45 adet lisansüstü tezi "yılı", "üniversitesi", "ana bilim dalı", "tez türü", "yazım dili", "çalışma konusu", "anahtar kelimeleri" ve "araştırma yöntemi" gibi değişkenlere göre incelemişlerdir. Araştırmanın bulgularına göre, yöresel yiyecekleri konu alan tezlerin çoğunluğu yüksek lisans tezlerinden oluşmaktadır. Yöresel yiyecekleri konu alan lisansüstü tezlerin \%41,2'sinde nicel, \%58,8'inde ise nitel yöntem kullanıldığı belirlenmiştir.

Tayfun vd., (2018) çalışmalarında, yiyecek ve içecek ile ilgili 1990-2018 yılları arasında hazırlanan lisansüstü tezleri incelemişlerdir. Çalışma kapsamında 164 tez analiz edilmiştir. Bulgulara göre, yiyecek ve içecek ile ilişkili tezlerin 2007 yılı itibariyle önemli bir artış gösterdiği, hazırlanan tezlerin çoğunlukla yüksek lisans tezi olduğu, en çok nicel yöntemler kullanıldığı ve örneklem grubunun daha çok turistler ve şeflerden oluştuğu belirlenmiştir. 
Kervankıran ve Şardağ (2019) çalışmalarında, turizm coğrafyası alanında yapılan 103 lisansüstü tezi; "nitelik", "konu", "literatür", "paradigma" ve "yöntem" açısından analiz etmişlerdir. Tezlerin büyük çoğunluğu yüksek lisans tezidir. İncelenen tezler sonucunda; turizm coğrafyası alanındaki nitelikli çalışmaların yetersiz olduğu ve tezlerin çoğunun teorik ve metodolojik olarak yetersiz olduğu görülmüştür.

Baytok vd., (2019) çalışmalarında, Afyon Kocatepe Üniversitesi'nde Turizm İşletmeciliği Anabilim Dalı bünyesinde tamamlanmış olan 40 yüksek lisans tezini incelenmişlerdir. Araştırmanın sonuçlarına göre, tezlerde veri toplama yönteminde nicel araştırma yönteminin ağırlıklı olarak kullanıldığı, örneklem gruplarında ise en fazla çalışanların ve turistlerin yer aldığ belirlenmiştir.

Literatürde, tezlerin incelendiği bibliyometrik çalışmalarda "tezlerin yayınlandığı yıl”, "tezlerin tamamlandığı üniversite", "tezlerin tamamlandığ enstitü", "tez sayıları", "tez türü", "araştırma konuları" "araştırma yöntemleri", "örneklem grupları" ve "anahtar kelimeler" en fazla kullanılan parametreler arasında olduğu görülmüştür. Turizm alanı ile ilgili en fazla lisansüstü tezlerinin Gazi Üniversitesi bünyesinden hazırlandığı belirlenirken, bunun nedeni olarak kuruluş tarihinin diğer birçok devlet üniversitesine kıyasla daha eski olmasından kaynaklandığı düşünülmektedir. Gastronomi alanı ile ilgili lisansüstü tezlerin özellikle az sayıda olduğu görülmüştür. Gastronomi alanının Türkiye'de son yıllarda popülerleşmesi, üniversitelerde açılan gastronomi yüksek lisans bölümlerinin eski tarihlere dayanmamasında dolayı gastronomi alanı ile lisansüstü tezlerin şu an için yeterli seviyede olmadığı düşünülmektedir. Ulusal literatürde tezlerin incelendiği bibliyometrik çalışmalarda özellikle çoğunluklu olarak nicel yöntemin ve anket tekniğinin tercih edildiği görülmüştür. Yapılan literatür taraması sonucunda, termal turizm alanında yayımlanan tezler ile ilgili herhangi bir bibliyometrik çalışmaya ulaşılamadığından dolayı literatürdeki bu boşluğu doldurmak amacıyla termal turizm alanındaki tezler incelenmiştir.

\section{YÖNTEM}

Bu makale çalışmasında, Yükseköğretim Kurumu Ulusal Tez Merkezi (YÖKTEZ) veri tabanında "termal turizm" alanında yayımlanan lisansüstü tezlerin çeşitli parametreler doğrultusunda bibliyometrik analizinin gerçekleştirilmesi amaçlanmıştır. Bu amaç doğrultusunda, çalışmada 1988-2019 yılları arasında yayımlanan termal turizmle ile ilgili lisansüstü tezleri araştırma kapsamına dahil edilmiştir. Çalışma kapsamındaki lisansüstü tezler için, YÖKTEZ arama motorunda "termal" ve "termal turizm" anahtar sözcükleri ile tarama yapılmıştır. 1988-2019 yılları arasında yayımlanan tezler kayıt altına alınarak bibliyometrik künyeleri elde edilmiştir. Araştırma ile ilgili veri toplama sürecine 1 Nisan 2019'da başlanmış ve 01 Mayıs 2019'da sona erdirilmiştir. Yapılan tarama sonucunda termal turizm ile ilgili 87'si yüksek lisans, 15'i doktora tezi olmak üzere toplam 102 lisansüstü teze ulaşılmıştır. 102 lisansüstü tezinden, 32 yüksek lisans ve 4 doktora tezinin yalnızca künye bilgilerine ulaşılmış olup, bu tezlerin künye bilgisinde yeterli veri olmadığı ve tam metinlerine ulaşılamadığ dahil edilmemişlerdir. Bu nedenle bu çalışmada Türkiye'de 1994-2019 yılları arasında yayımlanan lisansüstü tezlerin bibliyometrik özellikleri sırasıyla "yıl, üniversite, enstitü, anabilim dalları, anahtar kelimeler, araştırma yöntemleri, veri toplama teknikleri, örneklem grubu, araştırma konuları" açısından incelenmiştir. Veriler SPSS 18.0 paket programına aktarılıp, sıklık ve yüzdelik tabloları oluşturulmuştur. Bu bibliyometrik analiz çalışmasında aşağıdaki sorulara yanıt aranmışır:

a) Termal turizm alanında ayrıntısına ulaşılan ve ulaşılamayan tezlerin tamamlanma yıllarının dağılımı nasıldır?

b) Termal turizm alanında tez katkısı sağlayan üniversiteler hangileridir ve dağılımları nasıldır? 
c) Termal turizm alanında yazılan tezler hangi enstitüler altında tamamlanmış ve dağılımları nasıldır?

d) Termal turizm alanında yazılan tezler hangi anabilim dallarında tamamlanmış ve dağılımları nasıldir?

e) Termal turizm alanında yazılan tezlerde kullanılan anahtar kelimeler nelerdir ve dağılımları nasıldir?

f) Termal turizm alanında yazılan tezlerde kullanılan araştırma yöntemleri nelerdir ve dağılımları nasıldır?

g) Termal turizm alanında yazılan tezlerde hangi veri toplama teknikleri kullanılmış ve dağılımları nasıldır?

h) Termal turizm alanında yazılan tezlerde hangi örneklem grupları tercih edilmiş ve dağılımları nasıldir?

i) Termal turizm alanında yazılan tezlerde hangi konularda araştırmalar yapılmış ve dağılımları nasıldır?

\section{BULGULAR}

Bu bölümde YÖK Ulusal Tez Merkezi veri tabanında termal turizm ile ilgili ulaşılan ve ayrıntısına ulaşılamayan tezlerin tamamlanma yıllarına göre sıklık analizlerine ilişkin bulguları Tablo 1'de yer verilmektedir. Tamamlanan tezlerin yıllara göre dağılımı göz önünde bulundurulduğunda; en fazla tezin 2014 yılında yayımlandığı ortaya çıkmıştır. Yıllar itibariyle tezlerde düzenli artış veya azalış görülmemiştir. Termal turizm ile ilgili ulaşılamayan tezler incelediğinde ise yüksek lisans tezlerin doktora tezlerine kıyasla daha fazla olduğu görülmektedir. Tezlerin bu alanda sayıca yetersiz olması, araştırmacıların yıllar itibariyle farklı turizm alanlarına ilgi duymasının neden olduğu düşünülmektedir.

Tablo 1. Tezlerin Yıllara Göre Dağılımı

\begin{tabular}{|c|c|c|c|c|c|}
\hline \multicolumn{3}{|c|}{ Ulaşılan Tezler } & \multicolumn{3}{|c|}{ Ulaşılamayan Tezler } \\
\hline Y1l & Yüksek Lisans & Doktora & Y11 & Yüksek Lisans & Doktora \\
\hline 1994 & 1 & - & 1988 & 1 & - \\
\hline 1996 & 1 & - & 1992 & 2 & - \\
\hline 1997 & 2 & - & 1994 & 1 & - \\
\hline 2001 & 1 & - & 1995 & 2 & - \\
\hline 2005 & 2 & - & 1996 & 1 & 2 \\
\hline 2006 & 2 & - & 1997 & 1 & - \\
\hline 2007 & - & 2 & 1998 & 1 & - \\
\hline 2008 & 3 & 1 & 1999 & 1 & - \\
\hline 2009 & 5 & 2 & 2000 & 2 & - \\
\hline 2010 & 3 & 1 & 2001 & 2 & - \\
\hline 2011 & 4 & - & 2002 & 3 & 2 \\
\hline 2012 & 5 & 2 & 2005 & 1 & - \\
\hline 2013 & 7 & - & 2017 & 2 & - \\
\hline 2014 & 10 & 1 & 2018 & 2 & - \\
\hline 2015 & 7 & 1 & & & \\
\hline 2016 & 4 & 1 & & & \\
\hline 2017 & 3 & - & & & \\
\hline 2018 & 5 & - & & & \\
\hline Toplam & 65 & 11 & Toplam & 32 & 4 \\
\hline
\end{tabular}


Tablo 2' de lisansüstü tezlerin tamamlandığ 1 üniversitelerin listesi yer almaktadır. İlk üçte yer alan üniversiteler incelendiğinde, Afyon Kocatepe Üniversitesi bünyesinde 16, Balıkesir Üniversitesi bünyesinde 13, Dumlupınar Üniversitesi bünyesinde 5 tane tez hazırlandığı belirlenmiştir. Tablo incelendiğinde; en fazla tezin Afyon Kocatepe Üniversitesi $(\% 21,0)$ bünyesinde hazırlandığ 1 ortaya çıkmıştır. Afyonkarahisar ili, termal turizm açısından Türkiye'nin en önemli şehirlerinin başında gelmektedir. Afyon Kocatepe Üniversitesi bünyesinde hazırlanan termal turizm ile ilgili tezlerin daha fazla olması beklenen bir sonuç olarak düşünülmektedir.

Tablo 2. Tezlerin Üniversitelere Göre Dağılımı

\begin{tabular}{|c|c|c|}
\hline Üniversite & Siklık & $\%$ \\
\hline Afyon Kocatepe Üniversitesi & 16 & 21 \\
\hline Balıkesir Üniversitesi & 11 & 14.4 \\
\hline Dumlupınar Üniversitesi & 5 & 6.6 \\
\hline Selçuk Üniversitesi & 4 & 5.2 \\
\hline Düzce Üniversitesi & 4 & 5.2 \\
\hline Dokuz Eylül Üniversitesi & 3 & 3.9 \\
\hline Yıldız Teknik Üniversitesi & 2 & 2.6 \\
\hline İstanbul Üniversitesi & 2 & 2.6 \\
\hline Aksaray Üniversitesi & 2 & 2.6 \\
\hline Beykent Üniversitesi & 2 & 2.6 \\
\hline Niğde Üniversitesi & 2 & 2.6 \\
\hline Gazi Üniversitesi & 2 & 2.6 \\
\hline Eskişehir Osmangazi Üniversitesi & 2 & 2.6 \\
\hline Süleyman Demirel Üniversitesi & 1 & 1.3 \\
\hline Gaziosmanpaşa Üniversitesi & 1 & 1.3 \\
\hline Adnan Menderes Üniversitesi & 1 & 1.3 \\
\hline Nevşehir Hacı Bektaş Veli Üniversitesi & 1 & 1.3 \\
\hline Erciyes Üniversitesi & 1 & 1.3 \\
\hline İstanbul Ticaret Üniversitesi & 1 & 1.3 \\
\hline Zonguldak Bülent Ecevit Üniversitesi & 1 & 1.3 \\
\hline Karadeniz Teknik Üniversitesi & 1 & 1.3 \\
\hline Çanakkale Onsekiz Mart Üniversitesi & 1 & 1.3 \\
\hline Bozok Üniversitesi & 1 & 1.3 \\
\hline Çağ Üniversitesi & 1 & 1.3 \\
\hline Necmettin Erbakan Üniversitesi & 1 & 1.3 \\
\hline Batman Üniversitesi & 1 & 1.3 \\
\hline Akdeniz Üniversitesi & 1 & 1.3 \\
\hline Atatürk Üniversitesi & 1 & 1.3 \\
\hline Abant İzzet Baysal Üniversitesi & 1 & 1.3 \\
\hline İzmir Kâtip Çelebi Üniversitesi & 1 & 1.3 \\
\hline Okan Üniversitesi & 1 & 1.3 \\
\hline Cumhuriyet Üniversitesi & 1 & 1.3 \\
\hline Toplam & 76 & 100 \\
\hline
\end{tabular}

Tablo 3'te termal turizm ile ilgili tezlerin bağlı olduğu enstitüye göre dağılımı yer almaktadır. Hazırlanan tezlerin 68'i Sosyal Bilimler Enstitüsü bünyesinde, 4'ü Fen Bilimleri Enstitüsü 
bünyesinde, 3'ü Sağlık Bilimleri Enstitüsü bünyesinde ve 1'i de Eğitim Bilimleri Enstitüsü bünyesinde hazırlanmıştır. Bağlı olduğu enstitüye göre tezlerin dağılımı incelendiğinde; tezlerin en fazla "Sosyal Bilimler Enstitüsü" $(\% 89,4)$ bünyesinde tamamlandığ belirlenmiştir.

Tablo 3. Tezlerin Bağlı Olduğu Enstitüye Göre Dağılımı

\begin{tabular}{|l|c|c|}
\hline \multicolumn{1}{|c|}{ Enstitü } & S1klık & $\mathbf{\%}$ \\
\hline Sosyal Bilimleri Enstitüsü & 68 & 89.4 \\
\hline Fen Bilimleri Enstitüsü & 4 & 5.2 \\
\hline Sağllk Bilimleri Enstitüsü & 3 & 3.9 \\
\hline Eğitim Bilimleri Enstitüsü & 1 & 1.3 \\
\hline Toplam & $\mathbf{7 6}$ & $\mathbf{1 0 0}$ \\
\hline
\end{tabular}

Tablo 4'te tezlerin bağlı olduğu anabilim dallarına göre dağılımı yer almaktadır. Sıklık bakımından ilk üçte yer alan anabilim dalı incelendiğinde, 29 tezin İşletme Anabilim Dalında, 15 tezin Turizm İşletmeciliği ve Otelcilik Anabilim Dalında, 13 tezin Turizm İşletmeciliği Anabilim Dalında tamamlandığı görülmektedir. Buna göre; termal turizm alanında hazırlanan tezlerin en çok üniversitelerin İşletme Anabilim Dalı $(\% 38,1)$ bünyesinde tamamlandığı görülmektedir.

Tablo 4. Tezlerin Anabilim Dallarına Göre Dağılımı

\begin{tabular}{|l|c|c|}
\hline \multicolumn{1}{|c|}{ Anabilim Dalı } & S1klık & \% \\
\hline İşletme & 29 & 38.1 \\
\hline Turizm İșletmeciliği ve Otelcilik & 15 & 19.7 \\
\hline Turizm İletmeciliği & 13 & 17.1 \\
\hline Turizm ve Otel İşletmeciliği & 6 & 7.8 \\
\hline Jeoloji Mühendisliği & 2 & 2.6 \\
\hline Coğrafya & 2 & 2.6 \\
\hline Mimarlık & 2 & 2.6 \\
\hline Sağllk Yönetimi & 2 & 2.6 \\
\hline Beden Ĕğitimi ve Spor Bilimleri & 2 & 2.6 \\
\hline Turizm İşletmeciliği Eğitimi & 1 & 1.3 \\
\hline Orta Öğretim Sosyal Alanlar Ĕğitimi & 1 & 1.3 \\
\hline İktisat & 1 & 1.3 \\
\hline Toplam & $\mathbf{7 6}$ & $\mathbf{1 0 0}$ \\
\hline
\end{tabular}

Tablo 5'te tezlerde kullanılan anahtar kelimeler yer almaktadır. Bu dağılım incelendiğinde tezlerde anahtar kelimelerin seçiminde çoğunlukla ilk beş kelime sırasıyla; termal turizm, turizm, sağlık turizmi, hizmet kalitesi ve termal turizm işletmeleridir. 
Tablo 5. Tezlerde Kullanılan Anahtar Kelimelerin Dağılımı

\begin{tabular}{|c|c|}
\hline Anahtar Kelimeler & S1klık Sayısı \\
\hline Termal Turizm & 35 \\
\hline Turizm & 13 \\
\hline Sağllk Turizmi & 12 \\
\hline Hizmet Kalitesi & 9 \\
\hline Termal Turizm İşletmeleri & 8 \\
\hline Müşteri & 5 \\
\hline Termal otel & 5 \\
\hline Müşteri Memnuniyeti & 5 \\
\hline Kaplica & 4 \\
\hline Jeotermal & 3 \\
\hline Termal & 3 \\
\hline Bölgesel Kalkınma & 3 \\
\hline Hizmet & 3 \\
\hline Müşteri ilişkileri & 3 \\
\hline Halkla İlişkiler & 2 \\
\hline Tüketici Davranışları & 2 \\
\hline Müşteri Tatmini & 2 \\
\hline Kizilcahamam & 2 \\
\hline Turizm Pazarlaması & 2 \\
\hline Kalite & 2 \\
\hline Afyonkarahisar & 2 \\
\hline Konaklama İşletmeleri & 2 \\
\hline Türkiye & 2 \\
\hline Destinasyon & 2 \\
\hline Müşteri ilişkileri yönetimi & 2 \\
\hline Davranışsal Niyet & 2 \\
\hline Kütahya & 2 \\
\hline $\begin{array}{l}\text { Sadakat, sadakat nitelikleri, hata ve hile, işletme belge sistemi, reklamcılık, swot } \\
\text { analizi, müşteri şikayetleri, rekreatif, Nevşehir, traverten, tüketici algısı, } \\
\text { jeotermal kaynak, sürdürülebilir turizm, destinasyon imajı, otel özellikleri, } \\
\text { rekreasyon, spor, sağlık, yaşam, Çiftehan kaplıcaları, şehir imajı, şehir } \\
\text { pazarlama, turizmin etkileri, deneyimsel pazarlama, deneyim ekonomisi, } \\
\text { inovasyon, Pamukkale-Karahayıt, servqual, Antakya, satın alma karar süreci, } \\
\text { Ilgın kaplıcaları, girişimcilik, girişim, Balıkesir, Spa ve wellness otelleri, termal } \\
\text { turizm tesisleri, makro ve mikro planlama, Çanakkale, destinasyon geliştirme, } \\
\text { destinasyon pazarlaması, küreselleşme, uluslararası turizm, kurumsal } \\
\text { performans değerleme, kurumsal performans karnesi, ölçme ve değerleme, } \\
\text { amaç ve ölçütler, analitik hiyerarşi süreci, destinasyon rekabetçiliği, stratejik } \\
\text { planlama, marka, müşteri temelli marka değeri, marka algısı, turist, Balçova, } \\
\text { termal tesisler, güvenlik, tükenmişlik sendromu, pazarlama karması, İşgören, } \\
\text { yiyecek-içecek bölümü, alternatif turizm, beklenti, turizm çeşitlendirmesi, } \\
\text { termal kaynaklar, ekonomik değer, hasta memnuniyeti, sağlık hizmetleri } \\
\text { pazarlaması, termal işletmeler, internet, web siteleri, İç Anadolu Bölgesi, turizm } \\
\text { çeşitleri, stratejik yönetim, stratejik kalite yönetimi, Kazakistan, algllanan değer, } \\
\text { iş değer algısı, tekrar ziyaret niyetleri, termal otel işletmeleri, beş yıldızlı otel } \\
\text { işletmeleri, örgütsel vatandaşlık, ön büro, atık, katı atık, katı atık yönetimi, } \\
\text { örgütsel adalet, iş performansı, termal oteller, termal konaklama işletmesi, } \\
\text { rekabetçilik, ev pansiyonculuğu, beş güç modeli, çalışanlar, yeşil yıldız, çevre } \\
\text { yönetimi, kalite ölçümü, önem-performans analizi. }\end{array}$ & 1 \\
\hline
\end{tabular}


Tezlerde tercih edilen araştırma yöntemleri Tablo 6 'da yer almaktadır. Tabloya göre, 76 tezden 52 'sinde nicel, 20 tezde nitel araştırma yöntemi tercih edilirken, 2 tezde hem nicel hem de nitel araştırma yöntemi tercih edilmiştir. 2 tezde de hiçbir araştırma yöntemi kullanılmadığ görülmüştür. Buna göre araştırmacıların çoğunlukla nicel yöntemi $(\% 68,4)$ tercih ettikleri belirlenmiştir. Yıllar içerisinde istatistik programlarının gelişmesi, akademik danışmanların ve lisansüstü eğitimi alan öğrencilerin zaman içerisinde bu programlarla ilgili bilinçlenmesi ve bilgi düzeyinin artması termal turizm ile ilgili tez çalışmalarına da yansıdığı görülmektedir.

Tablo 6. Tezlerin Araştırma Yöntemleri

\begin{tabular}{|l|c|c|}
\hline Tez Araştırma Yöntemi & S1klık & $\mathbf{~}$ \\
\hline Nicel & 52 & 68.4 \\
\hline Nitel & 20 & 26.3 \\
\hline Karma & 2 & 2.6 \\
\hline Araştırma yöntemi yok & 2 & 2.6 \\
\hline Toplam & $\mathbf{7 6}$ & $\mathbf{1 0 0}$ \\
\hline
\end{tabular}

Tezlerde tercih edilen veri toplama teknikleri dağılımı Tablo $7^{\prime}$ de yer almaktadır. Tabloya göre; 76 tezden 52'sinde sadece anket tekniği, 8 tezde görüşme tekniği, 4 tezde görüşme ve gözlem tekniği bir arada, 3 tezde görüşme tekniği ve doküman analizi birlikte, 3 tezde sadece doküman analizi, 2 tezde görüşme ve anket tekniği bir arada kullanılırken, 2 tez içerik analizi kullanılarak hazırlanmıştır. 2 tezde de veri toplama tekniği olmadığı görülmüştür. Buna göre araştırmacıların çoğunlukla anket tekniğini $(\% 68,4)$ tercih ettikleri belirlenmiştir. Tezlerde çalışılan konular ve örneklem grupları göz önüne bulundurulduğunda, araştırma için çok sayıda kişiye ulaşılması gereken durumla karşılaşan araştırmacılar çoğunlukla, veri toplama tekniği olarak anketi tercih etmektedirler.

Tablo 7. Tezlerin Veri Toplama Tekniklerinin Dağılımı

\begin{tabular}{|l|c|c|}
\hline Veri Toplama Teknikleri & S1klık & $\mathbf{\%}$ \\
\hline Anket & 52 & 68.4 \\
\hline Görüşme & 8 & 10.5 \\
\hline Görüşme + gözlem & 4 & 5.2 \\
\hline Görüşme + doküman & 3 & 3.9 \\
\hline Doküman & 3 & 3.9 \\
\hline Görüşme + anket & 2 & 2.6 \\
\hline İçerik analizi & 2 & 2.6 \\
\hline Veri toplama tekniği yok & 2 & 2.6 \\
\hline Toplam & $\mathbf{7 6}$ & $\mathbf{1 0 0}$ \\
\hline
\end{tabular}

Tezlerde tercih edilen örneklem grubuna ilişkin dağılım Tablo 8'de yer almaktadır. Tabloya göre, 76 tezden sıklıkla tercih edilen örneklem grubunun ilk üçünde yer alan tezler incelendiğinde; 26 tezde yerli turistlerin, 11 tezde işletme yöneticilerinin ve 10 tezde de işletme çalışanlarının örneklem grubunda yer aldığı belirlenmiştir. Buna göre araştırmacıların örneklem grubu olarak çoğunlukla yerli turistleri $(\% 34,2)$ tercih ettikleri belirlenmiştir. Türkiye'de sağllk turizminin gün geçtikçe popüler hale gelmesi, termal turizm işletmelerinin sayısının artmasına da neden 
olmuştur. Bu durum göz önünde bulundurulduğunda, araştırmacılar özellikle termal turizm işletmelerine gelen turistlere, işletme yöneticilerine ve çalışanlarına yönelik araştırma yapmayı daha çok tercih ettikleri düşünülmektedir.

Tablo 8. Tezlerde Kullanılan Örneklem Grubuna İlişkin Dağılım

\begin{tabular}{|l|c|c|}
\hline Örneklem Grubu & Sıklık & $\mathbf{\%}$ \\
\hline Yerli turistler & 26 & 34.2 \\
\hline İşletme yöneticileri & 11 & 14.4 \\
\hline İ̧letme çalışanları & 10 & 13 \\
\hline Yerli turist +yabancı turist & 6 & 7.8 \\
\hline Örneklem grubu yok & 6 & 7.8 \\
\hline İsletme yöneticileri +yerli Turist & 3 & 3.9 \\
\hline İşletme yöneticileri+ işletme sahipleri & 2 & 2.6 \\
\hline İşletme yöneticileri+ İşletme çalışanları & 2 & 2.6 \\
\hline Otel siteleri & 2 & 2.6 \\
\hline İşletme yöneticileri+ yerel halk & 1 & 1.3 \\
\hline İşletme yöneticileri+ işletme çalışanları+yerli turist & 1 & 1.3 \\
\hline $\begin{array}{l}\text { İşletme yöneticileri+ işletme çalışanları+yerli } \\
\text { turist+yerel yönetim }\end{array}$ & 1 & 1.3 \\
\hline İşletme çalışanları+ yerli turist & 1 & 1.3 \\
\hline İletme yöneticileri +akademisyen & 1 & 1.3 \\
\hline Yerel halk+ yerel yönetim & 1 & 1.3 \\
\hline Girişimci & 1 & 1.3 \\
\hline Turizm ve çevre konularında uzman kişiler & 1 & 1.3 \\
\hline Toplam & $\mathbf{7 6}$ & $\mathbf{1 0 0}$ \\
\hline
\end{tabular}

Tezlerde tercih edilen araştırma konularına ilişkin dağılım Tablo 9'da yer almaktadır. Tabloya göre araştırmacıların sıklıkla tercih ettikleri ilk beş konu incelediğinde tezlerin 14'ünde yönetim ve organizasyonla ilgili konular, 11 tezde termal turizm potansiyeli, 9 tezde misafir memnuniyeti, 9 tezde tüketici davranışları ile ilgili konular ve 8 tezde de hizmet kalitesi ile ilgili konular üzerinde araştırma yaptıkları belirlenmiştir. Buna göre araştırmacıların en çok yönetim ve organizasyonla ilgili konuları tezlerinde $(\% 18,4)$ tercih ettikleri belirlenmiştir.

Danışmanlık yapan öğretim üyelerinin eğitim durumlarının ve çalıştıkları Anabilim dalının tez konusunun belirlenmesinde önemli katkı ve etkilerinin olduğu düşünülmektedir. Bu çalışmada da tamamlanan tezlerin İşletme ve Turizm İşletme Anabilim dallarında ağırlıklı olarak hazırlandığı, bu durumunda tez konularına etki ettiği görülmüştür.

Termal turizm ile ilgili tez çalışmalarının Afyon Kocatepe Üniversitesi ve Balıkesir Üniversitesi bünyesinde daha fazla çalışıldığı görülmektedir. Bu durum diğer bibliyometrik çalışmalarla karşılaştırıldığı benzerlik göstermemektedir (Güçlü Nergiz, 2014; Tayfun vd., 2016; Tekin, 2016; Civelek Oruç ve Türkay, 2017; Kılıç vd., 2017; Güdü Demirbulat ve Tetik Dinç, 2017; Sünnetçioğlu vd., 2017; İnce vd., 2017; Altaş ve Acar, 2018; Şahin vd., 2018; Ayaz ve Türkmen, 2018; Tayfun vd., 2018; Kervankıran ve Şardağ, 2019; Baytok vd.,2019). Çalışılan bibliyometrik konusu ve incelenen tez sayılarının da birbirinden farklı olması bu farklılı̆̆ın doğmasına neden olduğu düşünülmektedir. Termal turizm tezlerinin çoğunluğu Sosyal Bilimler Enstitüsü bünyesinde tamamlanmıştır. Turizm tezleri ile ilgili bibliyometrik çalışmalarda "tezlerin tamamlandığ 1 
enstitü" özelliğini inceleyen (Güçlü Nergiz, 2014; Güdü Demirbulat ve Tetik Dinç, 2017; Altaş ve Acar, 2018; Kılıç vd., 2017) çalışmalarda da tezlerin çoğunluğu Sosyal Bilimler Enstitüsü bünyesinde tamamlanmıştır. Bu çalışmada, tez araştırmalarında en çok nicel yöntem ve anket tekniğinin tercih edildiği görülmüştür. Turizm alanı ile ilgili tezleri değerlendiren bibliyometrik çalışmalarda "veri toplama yöntemi" ve "veri toplama tekniğini" özelliğini inceleyen çalışmalarda da (Kılıç vd., 2017; Sünnetçioğlu vd., 2017; İnce vd., 2017; Altaş ve Acar, 2018; Şahin vd., 2018; Tayfun vd., 2018; Kervankıran ve Şardağ, 2019; Baytok vd.,2019) en çok nicel yöntemin ve ankete tekniğinin kullanıldığı görülmüştür. Hem çalışılan konular açısından olsun hem de danışman faktörünün araştırma yöntemi ve tekniğinin belirlenmesinde önemli etkiye sahip olduğu düşünülmektedir.

Tablo 9. Tezlerde Kullanılan Araştırma Konuları

\begin{tabular}{|l|c|c|}
\hline Tez Araştırma Konuları & S1klık & $\mathbf{\%}$ \\
\hline Yönetim ve organizasyon & 14 & 18.4 \\
\hline Termal turizm potansiyeli & 11 & 14.4 \\
\hline Misafir memnuniyeti & 9 & 11.8 \\
\hline Tüketici davranışları & 9 & 11.8 \\
\hline Hizmet kalitesi & 8 & 10.5 \\
\hline Halkla ilişkiler -Müşteri ilişkileri & 4 & 5.2 \\
\hline Rekreasyon & 3 & 3.9 \\
\hline Deneyimsel pazarlama & 2 & 2.6 \\
\hline Termal turizmin bölgesel kalkınmaya etkisi & 2 & 2.6 \\
\hline Misafir şikâyetleri & 1 & 1.3 \\
\hline Muhasebe-finansman & 1 & 1.3 \\
\hline Termal otel tasarım & 1 & 1.3 \\
\hline İklim etkisi & 1 & 1.3 \\
\hline Termal kaynak & 1 & 1.3 \\
\hline Destinasyon imajı & 1 & 1.3 \\
\hline Marka imajı & 1 & 1.3 \\
\hline Termal turizmin yerel halka etkisi & 1 & 1.3 \\
\hline Çevreye duyarlılı & 1 & 1.3 \\
\hline Termal turizm tesis planlaması & 1 & 1.3 \\
\hline Turist sağlı̆̆ı ve güvenliği & 1 & 1.3 \\
\hline Pazarlama karması & 1 & 1.3 \\
\hline Destinasyon rekabetçiliği & 1 & 1.3 \\
\hline Marka Değeri & 1 & 1.3 \\
\hline Toplam & $\mathbf{7 6}$ & $\mathbf{1 0 0}$ \\
\hline
\end{tabular}

\section{SONUÇ VE ÖNERİLER}

1994-2019 yılları arasında Türkiye'de termal turizm alanında gerçekleştirilen lisansüstü tezlerin bibliyometrik analizinin yapılmasını amaçlayan bu çalışmada lisansüstü tezler; tamamlandığı yıl, üniversite, enstitü, anabilim dalları, kullanılan anahtar kelimeler, araştırma yöntemleri, veri toplama teknikleri, örneklem grubu ve araştırma konuları gibi değişkenler ele alınarak incelenmiştir. Turizm alanında termal turizm ile ilgili tezleri inceleyen çalışmaya ulaşılamaması nedeniyle bu araştırmanın önem arz edeceği düşünülmektedir. 
Yapılan çalışma sonucunda termal turizm alanında tamamlanan tezlerin çoğunlukla yüksek lisans tezi olduğu görülürken, doktora düzeyinde yapılan tezlerin çok sınırlı olduğu belirlenmiştir. Tezlerin bu alanda sayıca yetersiz olması, araştırmacıların yıllar itibariyle farklı turizm türlerine ilgi duymasının neden olduğu düşünülmektedir.

Bu alana katkı sağlayan üniversitelerin tez yayımlama sıralamalarına bakıldığında birinci sırada Afyon Kocatepe Üniversitesi'nin ön plana çıtığ görülmektedir. Tarihsel ve kültürel zenginlikleri yanında zengin jeotermal kaynakları bulunan Afyonkarahisar, termal turizm açısından Türkiye' nin en önemli şehirlerinin başında gelmektedir. Bu sebeple bu bölgede yer alan Afyon Kocatepe Üniversitesinin lisansüstü öğrencilerinin termal turizm ile ilgili araştırma yapmak istemeleri beklenen bir sonuçtur.

Termal turizm alanında yayımlanan tezlerin en fazla Sosyal Bilimler Enstitüsü'nde ve İşletme Anabilim Dallarında yayımlandığı görülmektedir. Ancak araştırma sonucunda elde edilen verilere bakıldığında farklı enstitü ve anabilim dallarında da çalışıldığı görülmüştür. Tezler incelendiğinde yönetim ve organizasyon konularının çoğunlukla tercih edildiği, örneklem grubu olarak da özellikle yöneticiler ve çalışanlar üzerinde araştırmalar yapıldı̆̆ı göz önünde bulundurulduğunda, İşletme Anabilim dalı bünyesinde yayımlanan tez sayısının fazla olması doğal bir durum olarak görülmektedir.

Yayımlanmış tezlerde en çok kullanılan veri toplama tekniğinin anket olduğu görülmektedir. Yıllar içerisinde istatistik programlarının gelişmesi, lisansüstü eğitim alan öğrencilerin bu programlarla ilgili zaman içerisinde bilgi düzeyinin artması ve anketin çok sayıda kişiye uygulanabilir olması, bu tekniğin seçilmesinde önemli sebepler olarak düşünülmektedir.

Bu araştırmada, yalnızca Yükseköğretim Kurumu Ulusal Tez Merkezi (YÖKTEZ) veri tabanında yer alan termal turizm ile ilgili paylaşıma açılmış tezlerin inceleme kapsamında olması araştırmanın sınırlılığıdır. Gelecekte bibliyometrik çalışmalara ilgi duyabilecek araştırmacıların paylaşıma açılmamış tezlere de ulaşarak daha kapsamlı bir değerlendirme yapmalarının faydalı olacağı düşünülmektedir. İlerleyen zamanlarda bu alana ilgi duyabilecek araştırmacıların tezler dışında termal turizm ile ilgili makale ve bildirilere de ulaşarak daha farklı parametreleri de kullanarak daha ayrıntılı inceleme yapmalarının yararlı olacağı düşünülmektedir. Diğer yandan bu araştırmanın gelecek yıllarda tekrar edilmesinin tez hazırlayan öğrencilere ve akademik danışmanlara araştırma konu ve tekniği belirleme aşamasında önemli bilgiler sunabileceği düşünülmektedir. Ayrıca Termal turizm ile ilgili ulusal ve uluslararası literatür karşılaştırmalarının gerçekleştirilmesi neticesinde bu alana yönelik ayrıntılı yaklaşımlara ulaşılması da mümkündür.

\section{KAYNAKÇA}

Afifi G. M.H. (2009) Tourism as the Subject of Doctoral Theses in Egypt, 1975-2008, Anatolia, 20(2): 387-400.

Altaş, A. ve Acar, Y. (2018). Bibliometric Profile of the Postgraduate Dissertations Written in the Field of Gastronomy, Aksaray Üniversitesi İktisadi ve İdari Bilimler Fakültesi Dergisi, 10(3): 1-10.

Ayaz, N. ve Türkmen, B. M. (2018). Yöresel Yiyecekleri Konu Alan Lisansüstü Tezlerin Bibliyometrik Analizi, Gastroia: Journal of Gastronomy and Travel Research, 2(1): 22-38.

Bao, J. (2002). Tourism Geography as The Subject of Doctoral Dissertations in China, 1989-2000, Tourism Geographies, 4: 148-152. 
Barrios, M., Boreego, A., Vilagines, A., Olle, C. and Somoza, M. (2008). A Bibliometric Study of Psychological Research on Tourism, Scientometrics, 77 (3):453-467.

Baytok, A., Boyraz, M., ve Pelit, E. (2019). Turizm İşletmeciliği Alanında Yapılan Yüksek Lisans Tezlerinin Değerlendirilmesi: Afyon Kocatepe Üniversitesi Örneği, Afyon Kocatepe University Journal of Social Sciences, 21(1): 287-305.

Civelek Oruç, M. ve Türkay, O. (2017). Turizmi Konu Alan Lisansüstü Çalışmalarının Bibliyometrik Analizi, International West Asia Congress of Tourism (Iwact'17), Van, 251-258.

Güdü Demirbulat, Ö. ve Tetik Dinç, N. (2017). Sürdürülebilir Turizm Konulu Lisansüstü Tezlerin Bibliyometrik Profili, Seyahat ve Otel İşletmeciliği Dergisi, 14 (2): 20-30.

İnce, M., Gül, H. ve Bozyiğit, S. (2017). Türkiye'de Turizm Pazarlaması Konusunda Yazılan Lisansüstü Tezlerin İçerik Analizi Yöntemiyle İncelenmesi: 1990-2016, Manas Sosyal Araştırmalar Dergisi, 6(5): 113-130.

Kervankıran, İ. and Şardağ, A. (2019). Tourism Geography Researches in Turkey: A Content Analysis for Graduate Theses, International Journal of Geography and Geography Education, 39: 151170 .

Kılıç A., Oflaz M., Acun A. ve Avcıkurt C. (2017). Girişimcilik Konulu Lisansüstü Tezlere Yönelik Bibliyometrik Bir Analiz, 8. Uluslararası Girişimcilik Kongresi, Balıkesir.

Güçlü Nergiz, H. (2014). Türkiye'de Lisansüstü Turizm Tezlerinin Bibliyometrik Profili (19902013), VII. Lisansüstü Turizm Öğrencileri Araştırma Kongresi 04-05 Nisan 2014, Kuşadası, $212-$ 221.

Meyer-Arendt, K. J. (2000). Commentary: Tourism Geography as The Subject of North American Doctoral Dissertations and Master's Theses, 1951-98, Tourism Geographies, 2(2): 140-156.

Meyer-Arendt, K. J., and Justice, C. (2002). Tourism as The Subject of North American Doctoral Dissertations, 1987-2000, Annals of Tourism Research, 29: 1171-1174.

Özel, Ç. H. ve Kozak, N. (2012). Turizm Pazarlaması Alanının Bibliyometrik Profili (2000-2010) ve Bir Atıf Analizi Çalışması, Türk Kütüphaneciliği, 26 (4): 715-733.

Sünnetçioğlu, A., Yalçınkaya, P., Olcay, M., ve Okan, Ş. (2017). Turizm Alanında Yazılmış Olan Gastronomiye İlişkin Tezlerin Bibliyometrik Profili, Journal of Tourism and Gastronomy Studies, 5(2): 345-354.

Şahin, E., Akdağ, G., Çakıcı, C., ve Onur, N. (2018). Gastronomi ve Mutfak Sanatları Anabilim Dallarında Yayınlanan Tezlerin Bibliyometrik Analizi, Güncel Turizm Araştırmaları Dergisi, 2(Ek1): 30-41.

Tayfun, A., Ülker, M., Gökçe, Y., Tengilimoğlu, E., Sürücü, Ç., ve Durmaz, M. (2018). Turizm Alanında Yiyecek ve İçecek ile İlgili Lisansüstü Tezlerin Bibliyometrik Analizi, Journal of Tourism and Gastronomy Studies, 6(2): 523-547.

Tayfun, A., Küçükergin, F. G., Aysen, E., Eren, A., ve Özekici, Y. K. (2016). Turizm Alanında Yazılan Lisansüstü Tezlere Yönelik Bibliyometrik Bir Analiz, Gazi Üniversitesi Turizm Fakültesi Dergisi, 1(1): 50-69.

Tekin, Ö. A. (2016). Türkiye'deki Lisansüstü Turizm Tezlerinde Odaklanılan Konular: 1984-2015, Uluslararası Alanya İşletme Fakültesi Dergisi, 8(2): 175-187. 
Tutar, E. (1991). Afyonkarahisar' da Termal Turizm Potansiyeli, Turizm Yıllığı 1991,Türkiye Kalkınma Bankası Yayını, Ankara. ss: 222-234.

Weiler B., Torland M., Moyle B. D. and Hadinejad A. (2018) Psychology-Informed Doctoral Research in Tourism, Tourism Recreation Research, 43(3): 277-288.

Yılmaz, G. (2017). Restoranlarda Bahşiş ile İlgili Yayınlanan Makalelerin Bibliyometrik Analizi, Seyahat ve Otel İşletmeciliği Dergisi, 14(2): 65-79.

Zengin, B. ve Eker, Nuray (2016). Sakarya İli Termal Turizm Potansiyelinin Değerlendirilmesi, Kastamonu Üniversitesi İktisadi ve İdari Bilimler Fakültesi Dergisi, 13(3): 165-181. 